\title{
Analisis Gangguan Muskuloskeletal Terhadap Perawat Berdasarkan Tingkat Paparan dengan Menggunakan Metode Movement and Assistance of Hospital Patients (mapo) Index (Studi kasus: RSUD Arifin Achmad Provinsi Riau)
}

\author{
Ekie Gilang Permata ${ }^{1}$, Abdurrahman Husni ${ }^{2}$ \\ ${ }^{1,2}$ Jurusan Teknik Industri, Fakultas Sains dan Teknologi, UIN Sultan Syarif Kasim Riau \\ Jl. HR. Soebrantas No. 155 Simpang Baru, Panam, Pekanbaru, 28293 \\ Email: ekiegilangpermata@uin-suska.ac.id, husniabdurrahman8@yahoo.co.id
}

\begin{abstract}
Abstrak
Terdapat 2 (dua) ruang rawat yang menjadi objek penelitian di rumah sakit ini, yaitu ruang Cenderawasih dan ruang Dahlia. Berdasarkan pengamatan awal menggunakan kuesioner Nordic Body Map diketahui bahwa secara umum para perawat mengalami gangguan muskuloskeletal terutama di bagian punggung dan pinggang. Perlu dilakukan analisis terhadap tingkat paparan gangguan muskuloskeletal para perawat tersebut. Salah satu metode analisisnya adalah MAPO Index. Dari hasil penelitian, nilai yang diperoleh pada ruang Cenderawasih adalah 5,44 dan ruang Dahlia adalah 5,78, dengan tingkat paparan yang terjadi pada kedua ruang rawat berada pada kategori Tinggi (Kode Merah). Perbaikan optimal yang perlu dilakukan yaitu dari segi Faktor Pelatihan (melakukan pelatihan) dan Faktor Bantuan Ringan (melengkapi alat bantu).
\end{abstract}

Kata Kunci: Evaluasi, Gangguan Muskuloskeletal, MAPO Index, Perawat, Tingkat Paparan.

\section{Latar Belakang}

Perawat adalah suatu profesi dimana harus menangani/merawat pasien selama 24 jam, termasuk di dalamnya aktivitas penanganan pasien secara manual seperti mengenakan pakaian, memandikan, dan sebagainya. Berdasarkan penelitian, diketahui bahwa profesi perawat di seluruh dunia memiliki risiko yang tinggi untuk mengalami gangguan muskuloskeletal akibat kerja Hignett (1996) merangkum 80 penelitian yang dipublikasi selama tiga dekade, menemukan kecenderungan Low Back Pain (nyeri pinggang) pada perawat lebih tinggi daripada populasi umum, terutama perawat yang banyak melakukan kegiatan angkat-angkut atau mobilisasi pasien (Kurniawidjaja dkk, 2014).

Musculoskeletal Disorder (MSDs)

merupakan sekumpulan gejala yang berkaitan dengan jaringan otot, tendon, ligamen, kartilago, sistem saraf, struktur tulang, dan pembuluh darah. MSDs atau gangguan muskuloskeletal awalnya menyebabkan rasa sakit, nyeri, mati rasa, kesemutan, bengkak, kekakuan, gemetar, gangguan tidur, dan rasa terbakar yang pada akhirnya mengakibatkan ketidakmampuan seseorang untuk melakukan pergerakan dan koordinasi gerakan anggota tubuh atau ekstrimitas sehingga dapat mengakibatkan efisiensi kerja berkurang dan poduktivitas kerja menurun (Humantech, 1995 dikutip oleh Bukhori, 2010).

Gangguan muskuloskeletal paling banyak ditemukan di tempat kerja terutama pada mereka yang beraktivitas dengan posisi tubuh yang salah. Pada perawat, posisi tubuh membungkuk dan menyamping merupakan postur-postur yang berisiko tinggi menyebabkan gangguan muskuloskeletal. Adapun faktor-faktor penyebab risiko lainnya termasuk berat dari pasien yang diangkut/dipindahkan, jumlah banyaknya menangani pasien, dan tingkat kekakuan postur tubuh selama bekerja. Hal ini dapat menjadi lebih buruk ketika peralatan angkat-angkut pasien seperti kursi roda, brankar, dan lain-lain dalam kondisi tidak baik ataupun rusak, serta kondisi ruangan rumah sakit yang sempit sehingga membatasi pergerakan perawat ketika memindahkan pasien.

Pada rumah sakit di Indonesia (terutama rumah sakit umum) sering ditemukan kondisi serupa, dimana peralatan yang umum digunakan untuk memindahkan pasien sering tidak memadai bahkan tidak tersedia. Begitu juga dengan alat angkut pasien yang sudah tersedia, perawatan terhadap peralatan tersebut tidak terlalu diperhatikan sehingga efektifitasnya menurun dan cenderung kurang nyaman ketika digunakan. Salah satu contoh rumah sakit dengan kondisi seperti ini adalah Rumah Sakit Umum Daerah (RSUD) Arifin Achmad Provinsi Riau. RSUD Arifin Achmad 
merupakan sebuah rumah sakit dengan status Satuan Kerja Perangkat Daerah (SKPD) yang dimiliki oleh pemerintah Provinsi Riau. Memiliki 17 jenis pelayanan dengan beberapa jenis ruang rawat diantaranya ruang rawat Kelas VIP, Kelas I, Kelas II, Kelas III, SCN, NICU, ICU, CVCU, PICU, HCU dan ruang Isolasi.

Berdasarkan pengamatan awal yang dilakukan, permasalahan seperti peralatan angkut pasien yang kurang tersedia serta perawatan yang tidak terlalu diperhatikan terhadap alat angkut banyak terjadi pada jenis ruang rawat Kelas II dan Kelas III. Jumlah pasien yang banyak juga menjadi faktor pendukung kurang diperhatikannya perawatan alat angkut tersebut mengingat tingkat penggunaannya yang cukup tinggi, dimana ruang rawat kelas II dihuni oleh $2-3$ pasien di dalam 1 ruangan, sedangkan untuk ruang rawat kelas III dihuni oleh 7 pasien di dalam 1 ruangan. Adapun pada bagian perawatan bedah, yaitu ruang Cenderawasih (Kelas II) dan ruang Dahlia (Kelas III), intensitas pemindahan pasien lebih tinggi dibandingkan dengan ruang rawat lainnya dikarenakan pasien bedah yang dirawat cukup beragam seperti pasien kecelakaan, ibu melahirkan, pasien pasca operasi, dan lain-lain, sehingga aktifitas perawat di kedua ruang tersebut juga cukup tinggi. Permasalahan lainnya yang terdapat pada kedua ruang tersebut antara lain seperti jumlah alat angkut pasien yang kurang memadai jika dibandingkan dengan jumlah pasien, bahkan pada beberapa kursi roda kondisinya kurang baik seperti rem yang tidak berfungsi serta juga sandaran tangan dan punggungnya yang tidak lagi nyaman. Alat bantu untuk memindahkan pasien dari brankar ke tempat tidur (ataupun sebaliknya) juga tidak tersedia sehingga pemindahan umumnya dilakukan manual (dengan mengangkat pasien), atau jika sangat diperlukan terkadang hanya menggunakan sprei atau selimut dari tempat tidur pasien. Jumlah pasien yang cukup banyak di dalam 1 ruangan (terutama ruang Dahlia) juga menyebabkan ruang gerak perawat ketika memindahkan pasien menjadi lebih terbatas sehingga postur tubuh cenderung kaku, ditambah lagi pelatihan keperawatan mengenai ergonomi perawat sudah cukup lama tidak dilakukan oleh pihak rumah sakit sehingga pengetahuan perawat dalam menangani permasalahan tersebut cukup minim. Dengan segala kondisi tersebut, maka risiko gangguan muskuloskeletal sangat mungkin terjadi pada para perawat.

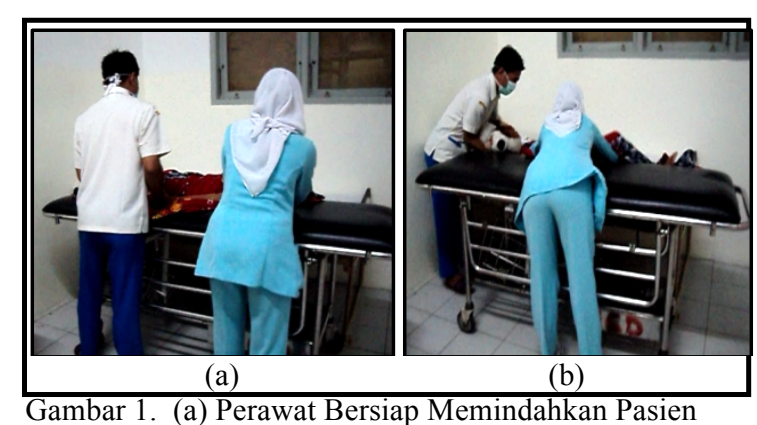

(b) Perawat Dalam Posisi Membungkuk

Hasil dokumentasi kegiatan memindahkan pasien pada gambar di atas memperlihatkan posisi tubuh dua orang perawat ketika bersiap untuk memindahkan pasien hingga saat memindahkan pasien, dimana terlihat posisi tubuh perawat cukup membungkuk, bahkan salah satu perawat terlihat sangat membungkuk. Posisi kerja yang salah seperti ini serta kecenderungan dalam melakukan kegiatan tersebut berulang-ulang sangat berpotensi menimbulkan gangguan muskuloskeletal pada para perawat tersebut. Hal ini tentu dapat dihindari jika alat bantu yang umum digunakan untuk memindahkan pasien (contohnya sliding sheet) tersedia.

Selain dokumentasi, dilakukan juga pengumpulan data awal terhadap para responden (dalam hal ini perawat) dengan menggunakan kuesioner Nordic Body Map yang bertujuan untuk mengetahui apakah para perawat mengalami gangguan muskuloskeletal atau tidak, serta bagian tubuh mana yang cenderung mengalami gangguan tersebut. Jumlah responden yang terlibat yaitu sebanyak 53 perawat, terbagi menjadi 18 perawat pada ruang Cenderawasih dan 35 perawat pada ruang Dahlia. Hasilnya, diketahui bahwa secara umum para perawat tersebut mengalami gangguan muskuloskeletal terutama di bagian punggung dan pinggang. Hal ini dapat dilihat pada point nomor 6 dan 8 pada Tabel 1, dimana jumlah responden yang merasakan keluhan hingga tingkat yang "Sakit" dan "Sakit Sekali" cukup meningkat secara signifikan pada kedua bagian tubuh ini dibandingkan dengan bagian tubuh yang lainnya.

Tabel 1 Rekapitulasi Hasil Pengisian Kuesioner Nordic Body Map

\begin{tabular}{|c|l|c|c|c|c|}
\hline \multirow{2}{*}{ No } & \multirow{2}{*}{ Jenis Keluhan } & \multicolumn{4}{|c|}{ Tingkat Keluhan } \\
\cline { 3 - 6 } & $\begin{array}{c}\text { Tidak } \\
\text { Sakit }\end{array}$ & $\begin{array}{c}\text { Agak } \\
\text { Sakit }\end{array}$ & Sakit & $\begin{array}{c}\text { Sakit } \\
\text { Sekali }\end{array}$ \\
\hline 1 & $\begin{array}{l}\text { Sakit/kaku pada } \\
\text { leher bagian atas }\end{array}$ & 21 & 27 & 3 & 2 \\
\hline 2 & $\begin{array}{l}\text { Sakit/kaku pada } \\
\text { leher bagian bawah }\end{array}$ & 31 & 18 & 2 & 2 \\
\hline 3 & Sakit pada bahu kiri & 33 & 18 & 2 & - \\
\hline 4 & $\begin{array}{l}\text { Sakit pada bahu } \\
\text { kanan }\end{array}$ & 32 & 18 & 2 & 1 \\
\hline 5 & Sakit pada lengan & 39 & 12 & 2 & - \\
\hline
\end{tabular}


Vol. 2, No. 1, 2016

Jurnal Hasil Penelitian dan Karya Ilmiah dalam Bidang Teknik Industri

\begin{tabular}{|c|l|c|c|c|c|}
\hline & atas kiri & & & & \\
\hline 6 & $\begin{array}{l}\text { Sakit pada } \\
\text { punggung }\end{array}$ & 18 & 17 & 14 & 4 \\
\hline 7 & $\begin{array}{l}\text { Sakit pada lengan } \\
\text { atas kanan }\end{array}$ & 37 & 13 & 1 & 2 \\
\hline 8 & $\begin{array}{l}\text { Sakit pada } \\
\text { pinggang }\end{array}$ & 14 & 7 & 25 & 7 \\
\hline 9 & $\begin{array}{l}\text { Sakit pada } \\
\text { bokong }\end{array}$ & 34 & 17 & 1 & 1 \\
\hline 10 & Sakit pada pantat & 32 & 17 & 3 & 1 \\
\hline 11 & $\begin{array}{l}\text { Sakit pada siku } \\
\text { kiri }\end{array}$ & 49 & 4 & - & - \\
\hline 12 & $\begin{array}{l}\text { Sakit pada siku } \\
\text { kanan }\end{array}$ & 47 & 6 & - & - \\
\hline 13 & $\begin{array}{l}\text { Sakit pada lengan } \\
\text { bawah kiri }\end{array}$ & 43 & 10 & - & - \\
\hline 14 & $\begin{array}{l}\text { Sakit pada lengan } \\
\text { bawah kanan }\end{array}$ & 40 & 13 & - & - \\
\hline 15 & $\begin{array}{l}\text { Sakit pada } \\
\text { pergelangan } \\
\text { tangan kiri }\end{array}$ & 41 & 9 & 3 & - \\
\hline 16 & $\begin{array}{l}\text { Sakit pada } \\
\text { pergelangan } \\
\text { tangan kanan }\end{array}$ & 40 & 10 & 2 & 1 \\
\hline 17 & $\begin{array}{l}\text { Sakit pada tangan } \\
\text { kiri }\end{array}$ & 44 & 7 & 2 & - \\
\hline 18 & $\begin{array}{l}\text { Sakit pada tangan } \\
\text { kanan }\end{array}$ & 42 & 9 & 1 & 1 \\
\hline 19 & $\begin{array}{l}\text { Sakit pada paha } \\
\text { kiri }\end{array}$ & 43 & 7 & 3 & - \\
\hline 20 & $\begin{array}{l}\text { Sakit pada paha } \\
\text { kanan }\end{array}$ & 43 & 7 & 2 & 1 \\
\hline 21 & $\begin{array}{l}\text { Sakit pada lutut } \\
\text { kiri }\end{array}$ & 38 & 13 & 2 & - \\
\hline 22 & $\begin{array}{l}\text { Sakit pada lutut } \\
\text { kanan }\end{array}$ & 34 & 16 & 3 & - \\
\hline 23 & $\begin{array}{l}\text { Sakit pada betis } \\
\text { kiri }\end{array}$ & 30 & 19 & 4 & - \\
\hline 24 & $\begin{array}{l}\text { Sakit pada betis } \\
\text { kanan }\end{array}$ & 30 & 20 & 2 & 1 \\
\hline 25 & $\begin{array}{l}\text { Sakit pada } \\
\text { pergelangan kaki } \\
\text { kiri }\end{array}$ & 39 & 10 & 4 & - \\
\hline 7 & 1 Rekaptula & \\
\hline
\end{tabular}

Tabel 1 Rekapitulasi Hasil Pengisian Kuesioner Nordic

\begin{tabular}{|c|l|c|c|c|c|}
\hline \multirow{2}{*}{ No } & \multirow{2}{*}{ Jenis Keluhan } & \multicolumn{4}{|c|}{ Tingkat Keluhan } \\
\cline { 3 - 6 } & $\begin{array}{c}\text { Tidak } \\
\text { Sakit }\end{array}$ & $\begin{array}{c}\text { Agak } \\
\text { Sakit }\end{array}$ & Sakit & $\begin{array}{c}\text { Sakit } \\
\text { Sekali }\end{array}$ \\
\hline 26 & $\begin{array}{l}\text { Sakit pada } \\
\text { pergelangan kaki } \\
\text { kanan }\end{array}$ & 40 & 12 & - & 1 \\
\hline 27 & Sakit pada kaki kiri & 42 & 11 & - & - \\
\hline 28 & $\begin{array}{l}\text { Sakit pada kaki } \\
\text { kanan }\end{array}$ & 43 & 9 & - & 1 \\
\hline
\end{tabular}

Berdasarkan permasalahan yang terjadi serta hasil yang diperoleh dari pengumpulan data awal menunjukkan bahwa kondisi seperti ini sangat berpengaruh terhadap gangguan muskuloskeletal perawat. Dalam kurun waktu yang berkepanjangan, hal ini tentu akan memberi pengaruh buruk bagi kesehatan perawat serta dapat menurunkan tingkat produktifitas kerjanya. Untuk mengatasi segala permasalahan tersebut, maka perlu dilakukan analisis terhadap tingkat paparan gangguan muskuloskeletal perawat berdasarkan faktor-faktor yang terkait. Salah satu metode analisis khusus untuk menilai tingkat gangguan muskuloskeletal pada perawat tersebut adalah MAPO Index.
Adapun rumusan masalah pada penelitian ini adalah bagaimana analisis gangguan muskuloskeletal terhadap perawat berdasarkan tingkat paparan dengan menggunakan metode Movement and Assistance of Hospital Patients (MAPO) Index (Studi Kasus: RSUD Arifin Achmad Provinsi Riau).

\section{Metode Penelitian}

Metodologi penelitian merupakan deskripsi dari seluruh rangkaian kegiatan yang dilaksanakan selama proses penelitian, yakni dari awal kegiatan sampai dengan akhir penelitian. Metodologi penelitian digunakan untuk mengarahkan serta mempermudah proses pemecahan masalah dan menganalisa hasil pengolahan melalui manajemen penelitian yang baik sehingga penelitian yang dilakukan dapat menjadi lebih berkualitas. Setiap tahapan dalam metodologi penelitian adalah bagian yang penting sehingga harus dilakukan dengan baik dan teliti. Adapun uraian langkah-langkah penelitian tersebut adalah sebagai berikut.

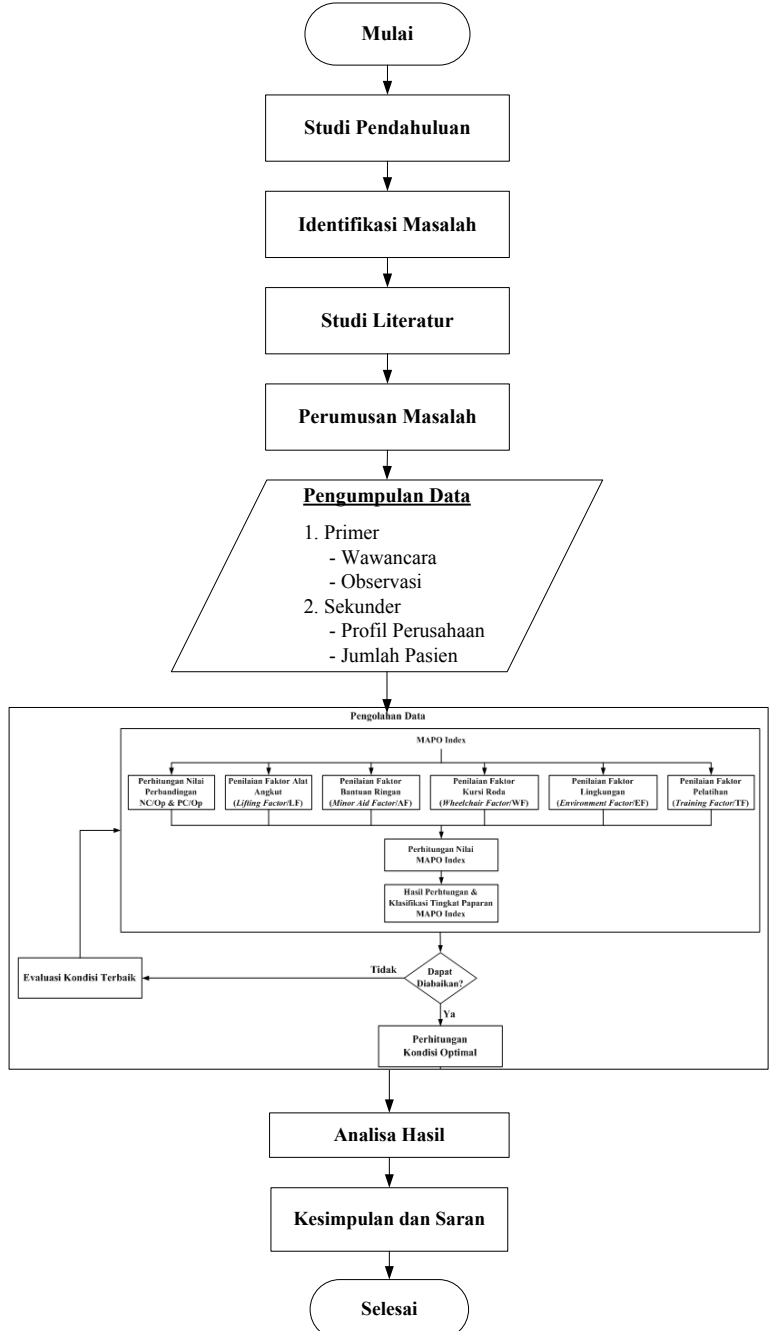

Gambar 2. Flowchart Metode Penelitian 


\section{Hasil dan Pembahasan}

Pengolahan data dilakukan berdasarkan penilaian terhadap indikator yang terdapat dalam MAPO Index.

\section{Hasil Penilaian MAPO Index Ruang Cenderawasih}

1. Perhitungan Nilai Perbandingan NC/Op \& $\mathrm{PC} / \mathrm{Op}$

Diketahui:
a. Jumlah Perawat Bekerja $=14$ Orang
b. Jumlah Pasien $\mathrm{NC}=3$ Orang
c. Jumlah Pasien $\mathrm{PC}=29$ Orang

Tabel 2. Perhitungan Nilai Perbandingan NC/Op \& PC/Op Ruang Cenderawasih

\begin{tabular}{|l}
\hline \multicolumn{3}{|c|}{ JUMLAH PASIEN LUMPUH (BUTUH BANTUAN)/BANYAKNYA } \\
OPERATOR
\end{tabular}

Diketahui:

a. Kondisi alat angkut Layak dan Baik $\approx$ Memadai

b. Jumlah alat angkut $\approx$ Cukup

Tabel 3. Penilaian Faktor Alat Angkut (Lifting Factor/LF) Ruang Cenderawasih

\begin{tabular}{|c|c|c|}
\hline FAKTOR ALAT ANGKUT (LF) & $\begin{array}{c}\text { PENILAIAN } \\
\text { LF }\end{array}$ & \multirow{4}{*}{$\stackrel{\llcorner\mathbf{L F}}{\llcorner 0,5\rfloor}$} \\
\hline Alat Angkut TIDAK ADA & 4 & \\
\hline $\begin{array}{l}\text { Alat Angkut TIDAK MEMADAI atau TIDAK } \\
\text { CUKUP }\end{array}$ & 2 & \\
\hline Alat Angkut MEMADAI da & 0,5 & \\
\hline
\end{tabular}

3. Penilaian Faktor Bantuan Ringan (Minor Aid Factor/AF)

Diketahui:

Tidak ada alat bantu apapun.

Tabel 4. Penilaian Faktor Bantuan Ringan (Minor Aid Factor/AF) Ruang Cenderawasih

\begin{tabular}{|l|c|c|c|}
\hline \multicolumn{2}{|c|}{ FAKTOR BANTUAN RINGAN (AF) } & $\begin{array}{c}\text { PENILAIAN } \\
\text { AF }\end{array}$ & \multirow{2}{*}{ Af AF } \\
\hline $\begin{array}{l}\text { Bantuan Ringan TIDAK ADA atau TIDAK } \\
\text { TERSEDIA }\end{array}$ & $\sqrt{ }$ & 1 & \\
\hline Bantuan Ringan MEMADAI dan TERSEDIA & & $\mathbf{0 , 5}$ & \\
\hline
\end{tabular}

4. Penilaian Faktor Kursi Roda (Wheelchair Factor/WF)

Diketahui:

a. Penilaian Kondisi Kursi Roda

Nilai Rata-rata Kursi Roda (MSWh) $=1$

b. Jumlah Kursi Roda $\approx$ Tidak Cukup

Tabel 5. Penilaian Faktor Kursi Roda (Wheelchair Factor/WF) Ruang Cenderawasih

\begin{tabular}{|c|c|c|c|c|c|c|c|}
\hline \multicolumn{7}{|c|}{ FAKTOR KURSI RODA (WF) } & \multirow{4}{*}{$\left\lfloor\frac{1}{\mathbf{W}} \mid\right.$} \\
\hline $\begin{array}{l}\text { Nilai Rata-rata Kursi } \\
\text { Roda (MSWh) }\end{array}$ & \multicolumn{2}{|c|}{$0,5-1,33$} & \multicolumn{2}{|c|}{$1,34-2,66$} & \multicolumn{2}{|c|}{$2,67-4$} & \\
\hline $\begin{array}{l}\text { Jumlah Kursi Roda } \\
\text { Memadai }\end{array}$ & YES & NO & YES & NO & YES & NO & \\
\hline PENILAIAN WF & 0,75 & 1 & 1,12 & 1,5 & 1,5 & 2 & \\
\hline
\end{tabular}

5. Penilaian Faktor Lingkungan (Environment Factor/EF)

Diketahui:

a. Penilaian Kondisi Kamar Rawat Nilai Rata-rata Ruang Rawat (MSW) $=2,73$

b. Penilaian Kondisi Kamar Mandi Nilai Rata-rata Kamar Mandi $(\mathbf{M S B})=1$

c. Penilaian Kondisi WC/Toilet Nilai Rata-rata WC/Toilet $(\mathbf{M S W C})=4$

d. Nilai Rata-rata Lingkungan Nilai Rata-rata Lingkungan $($ MSE) $=7,73$

Tabel 6. Penilaian Faktor Lingkungan (Environment Factor/EF) Ruang Cenderawasih

\begin{tabular}{|c|c|c|c|c|}
\hline \multicolumn{4}{|c|}{ FAKTOR LINGKUNGAN (EF) } & \multirow{3}{*}{$|1,25| \mathbf{E F}$} \\
\hline MSE & $0-5,8$ & $5,9-11,6$ & $11,7-17,5$ & \\
\hline PENILAIAN EF & 0,75 & 1,25 & 1,5 & \\
\hline
\end{tabular}

6. Penilaian Faktor Pelatihan (Training Factor/TF)

Diketahui:

Tidak ada dilakukan pelatihan.

Tabel 7. Penilaian Faktor Pelatihan (Training Factor/TF) Ruang Cenderawasih

\begin{tabular}{|l|c|c|c|}
\hline \multicolumn{2}{|c|}{ FAKTOR PELATIHAN (TF) } & PENILAIAN TF & \multirow{2}{*}{$\mid$ 2_ $\mid$ TF } \\
\hline Pelatihan Diadakan & & $\mathbf{0 , 7 5}$ & \\
\hline Hanya Berupa Informasi & & $\mathbf{1}$ & \\
\hline Tidak Ada Pelatihan & $\sqrt{ }$ & $\mathbf{2}$ & \\
\hline
\end{tabular}

7. Perhitungan Nilai dan Pengklasifikasian Tingkat Paparan MAPO Index

$$
\begin{aligned}
\text { MAPO } & =(0,21 \times 0,5+2,07 \times 1) \times 1 \times 1,25 \times 2 \\
& =(0,105+2,07) \times 2,5 \\
& =2,175 \times 2,5 \\
& =5,44 \approx \text { Tinggi (Kode Merah) }
\end{aligned}
$$

\section{Hasil Penilaian MAPO Index Ruang Dahlia}

1. Perhitungan Nilai Perbandingan NC/Op \& $\mathrm{PC} / \mathrm{Op}$
Diketahui:
a. Jumlah Perawat Bekerja $=24$ Orang
b. Jumlah Pasien $\mathrm{NC}=3$ Orang

\begin{tabular}{|c|c|c|}
\hline \multicolumn{3}{|c|}{$\begin{array}{l}\text { JUMLAH PASIEN LUMPUH (BUTUH BANTUAN)/BANYAKNYA } \\
\text { OPERATOR }\end{array}$} \\
\hline $\begin{array}{l}\text { Pasien } \\
24=\end{array}$ & Operator & 0,125 NC/Op \\
\hline $\begin{array}{l}\text { Pasien Partially-Cooperative (PC) } \quad 54 \text { oran } \\
24=\end{array}$ & Operator & $2,25 \quad \mathbf{P C} / \mathbf{O p}$ \\
\hline
\end{tabular}
c. Jumlah Pasien $\mathrm{PC}=54$ Orang

Tabel 8. Perhitungan Nilai Perbandingan NC/Op \& PC/Op Ruang Dahlia

2. Penilaian Faktor Alat Angkut (Lifting Factor/LF)

Diketahui:

a. Kondisi alat angkut Layak dan Baik $\approx$ Memadai

b. Jumlah alat angkut $\approx$ Cukup 
Tabel 9. Penilaian Faktor Alat Angkut (Lifting Factor/LF) Ruang Dahlia

\begin{tabular}{|c|c|c|c|}
\hline FAKTOR ALAT ANGKUT (LF) & & $\begin{array}{l}\text { PENILAIAN } \\
\text { LF }\end{array}$ & \multirow{4}{*}{$\left|\frac{0,5}{\mathbf{L F}}\right|$} \\
\hline Alat Angkut TIDAK ADA & & 4 & \\
\hline $\begin{array}{l}\text { Alat Angkut TIDAK MEMADAI atau TIDAK } \\
\text { CUKUP }\end{array}$ & & 2 & \\
\hline Alat Angkut MEMADAI dan CUKUP & $\sqrt{ }$ & 0,5 & \\
\hline
\end{tabular}

3. Penilaian Faktor Bantuan Ringan (Minor Aid Factor/AF)

Diketahui:

Hanya terdapat 1 buah alat bantu.

Tabel 10. Penilaian Faktor Bantuan Ringan (Minor Aid Factor/AF) Ruang Dahlia

\begin{tabular}{|c|c|c|c|}
\hline \multicolumn{2}{|l|}{ FAKTOR BANTUAN RINGAN (AF) } & $\begin{array}{l}\text { PENILAIAN } \\
\text { AF }\end{array}$ & \\
\hline $\begin{array}{l}\text { Bantuan Ringan TIDAK ADA atau TIDAK } \\
\text { TERSEDIA }\end{array}$ & $\sqrt{ }$ & 1 & $1 \mid \mathbf{A F}$ \\
\hline Bantuan Ringan MEMADAI dan TERSEDIA & & 0,5 & \\
\hline
\end{tabular}

4. Penilaian Faktor Kursi Roda (Wheelchair Factor/WF)

Diketahui:

a. Penilaian Kondisi Kursi Roda

Nilai Rata-rata Kursi Roda (MSWh) $=0,75$

b. Jumlah Kursi Roda $\approx$ Tidak Cukup

Tabel 11.Penilaian Faktor Kursi Roda (Wheelchair Factor/WF) Ruang Dahlia

\begin{tabular}{|l|c|c|c|c|c|c|c|}
\hline \multicolumn{7}{|c|}{ FAKTOR KURSI RODA (WF) } & \\
\cline { 1 - 6 } $\begin{array}{l}\text { Nilai Rata-rata Kursi } \\
\text { Roda (MSWh) }\end{array}$ & \multicolumn{2}{|c|}{$0,5-1,33$} & \multicolumn{2}{|c|}{$1,34-2,66$} & \multicolumn{2}{|c|}{$2,67-4$} \\
\cline { 1 - 4 } $\begin{array}{l}\text { Jumlah Kursi Roda } \\
\text { Memadai }\end{array}$ & YES & NO & YES & NO & YES & NO & \\
\hline PENILAIAN WF & $\mathbf{0 , 7 5}$ & $\mathbf{1}$ & $\mathbf{1 , 1 2}$ & $\mathbf{1 , 5}$ & $\mathbf{1 , 5}$ & $\mathbf{2}$ & \\
\hline
\end{tabular}

5. Penilaian Faktor Lingkungan (Environment Factor/EF)

Diketahui:

a. Penilaian Kondisi Kamar Rawat Nilai Rata-rata Ruang Rawat (MSW) $=3,23$

b. Penilaian Kondisi Kamar Mandi Nilai Rata-rata Kamar Mandi $($ MSB $)=1$

c. Penilaian Kondisi WC/Toilet Nilai Rata-rata WC/Toilet $(\mathbf{M S W C})=2$

d. Nilai Rata-rata Lingkungan Nilai Rata-rata Lingkungan (MSE) $=6,23$

Tabel 12. Penilaian Faktor Lingkungan (Environment Factor/EF) Ruang Dahlia

\begin{tabular}{|l|c|c|c|c|}
\hline \multicolumn{4}{|c|}{ FAKTOR LINGKUNGAN (EF) } & \multirow{2}{*}{$|1,25|$ EF } \\
\hline MSE & $0-5,8$ & $5,9-11,6$ & $11,7-17,5$ & \multirow{2}{|c|}{$\mid$} \\
\hline PENILAIAN EF & $\mathbf{0 , 7 5}$ & $\mathbf{1 , 2 5}$ & $\mathbf{1 , 5}$ & \\
\hline
\end{tabular}

6. Penilaian Faktor Pelatihan (Training Factor/TF)

Diketahui:

Tidak ada dilakukan pelatihan.
Tabel 13.Penilaian Faktor Pelatihan (Training Factor/TF) Ruang Dahlia

\begin{tabular}{|l|c|c|c|}
\hline \multicolumn{2}{|c|}{ FAKTOR PELATIHAN (TF) } & PENILAIAN TF & \multirow{2}{*}{ 2_」 TF } \\
\cline { 1 - 3 } Pelatihan Diadakan & & $\mathbf{0 , 7 5}$ & \\
\hline Hanya Berupa Informasi & & $\mathbf{1}$ & \\
\hline Tidak Ada Pelathan & $\sqrt{ }$ & $\mathbf{2}$ & \\
\hline
\end{tabular}

7. Perhitungan Nilai dan Pengklasifikasian Tingkat Paparan MAPO Index

$$
\begin{aligned}
\text { MAPO } & =(0,125 \times 0,5+2,25 \times 1) \times 1 \times 1,25 \times 2 \\
& =(0,063+2,25) \times 2,5 \\
& =2,31 \times 2,5 \\
& =5,78 \approx \text { Tinggi (Kode Merah) }
\end{aligned}
$$

\section{Evaluasi Kondisi Terbaik Ruang Cenderawasih}

1. Perhitungan Nilai Perbandingan NC/Op \& $\mathrm{PC} / \mathrm{Op}$

Kondisi terbaik yang ditetapkan adalah melakukan penambahan jumlah perawat yang optimal. Berdasarkan metode Douglas, diketahui jumlah perawat optimal pada ruang Cenderawasih adalah 18

\begin{tabular}{|c|c|c|}
\hline \multicolumn{3}{|c|}{$\begin{array}{l}\text { JUMLAH PASIEN LUMPUH (BUTUH BANTUAN)/BANYAKNYA } \\
\text { OPERATOR }\end{array}$} \\
\hline $\begin{array}{l}\text { Pasien Non-Cooperative (NC) } 3 \text { orang } \\
18=\end{array}$ & Operator & $0,17 \_\mathbf{N C} / \mathbf{O p}$ \\
\hline $\begin{array}{l}\text { Pasien Partially-Cooperative (PC) _ } 29 \text { _or } \\
18=\end{array}$ & Operator & $1,61 \quad \mathbf{P C} / \mathbf{O p}$ \\
\hline
\end{tabular}
orang, dengan jumlah perawat keseluruhan 24 orang.

Tabel 14. Perhitungan Nilai Perbandingan NC/Op \& PC/Op Ruang Cenderawasih (Kondisi Terbaik)

2. Penilaian Faktor Alat Angkut (Lifting Factor/LF)

Penetapan kondisi terbaik tidak dilakukan mengingat kondisi yang ada sekarang sudah cukup baik bagi ruang rawat.

3. Penilaian Faktor Bantuan Ringan (Minor Aid Factor/AF)

Kondisi terbaik yang ditetapkan pada indikator ini adalah dilengkapinya alat bantu (2 buah

\begin{tabular}{|c|c|c|}
\hline FAKTOR BANTUAN RINGAN (AF) & $\begin{array}{l}\text { PENILAIAN } \\
\text { AF }\end{array}$ & \\
\hline $\begin{array}{l}\text { Bantuan Ringan TIDAK ADA atau TIDAK } \\
\text { TERSEDIA }\end{array}$ & 1 & ${ }_{\mathbf{A F}}^{0,5}$ \\
\hline Bantuan Ringan MEMADAI dan TERSEDIA & 0,5 & \\
\hline
\end{tabular}
Sliding Sheet +1 buah Long Spin Board)

Tabel 15. Penilaian Faktor Bantuan Ringan (Minor Aid Factor/AF) Ruang Cenderawasih (Kondisi Terbaik)

4. Penilaian Faktor Kursi Roda (Wheelchair Factor/WF)

Kondisi terbaik yang ditetapkan pada indikator ini adalah dilakukan penambahan kursi roda pada ruang tersebut hingga total kursi roda berjumlah 14 buah. 
Tabel 16. Penilaian Faktor Kursi Roda (Wheelchair Factor/WF) Ruang Cenderawasih (Kondisi Terbaik)

\begin{tabular}{|c|c|c|c|c|c|c|c|}
\hline \multicolumn{7}{|c|}{ FAKTOR KURSI RODA (WF) } & \multirow{4}{*}{$\left\lfloor-\frac{0,75}{\mathbf{W F}} \mid\right.$} \\
\hline $\begin{array}{l}\text { Nilai Rata-rata Kursi } \\
\text { Roda (MSWh) }\end{array}$ & \multicolumn{2}{|c|}{$0,5-1,33$} & \multicolumn{2}{|c|}{$1,34-2,66$} & \multicolumn{2}{|c|}{$2,67-4$} & \\
\hline $\begin{array}{l}\text { Jumlah Kursi Roda } \\
\text { Memadai }\end{array}$ & YES & NO & YES & NO & YES & $\mathrm{NO}$ & \\
\hline PENILAIAN WF & 0,75 & 1 & 1,12 & 1,5 & 1,5 & 2 & \\
\hline
\end{tabular}

5. Penilaian Faktor Lingkungan (Environment Factor/EF)

Kondisi terbaik yang ditetapkan pada indikator ini adalah dilakukan perancangan ulang serta melengkapi ataupun mengganti fitur-fitur yang bermasalah terhadap aspek-aspek terkait. Dengan demikian, maka diketahui:
a. Penilaian Kondisi Kamar Rawat
Nilai Rata-rata Ruang Rawat (MSW) $=0$
b. Penilaian Kondisi Kamar Mandi
Nilai Rata-rata Kamar Mandi $(\mathbf{M S B})=0$
c. Penilaian Kondisi WC/Toilet
Nilai Rata-rata WC/Toilet $(\mathbf{M S W C})=0$
d. Nilai Rata-rata Lingkungan
Nilai Rata-rata Lingkungan (MSE) $=0$

Tabel 17. Penilaian Faktor Lingkungan (Environment Factor/EF) Ruang Cenderawasih (Kondisi Terbaik)

\begin{tabular}{|c|c|c|c|c|}
\hline \multicolumn{4}{|c|}{ FAKTOR LINGKUNGAN (EF) } & \multirow{3}{*}{$|\underline{0,75}| \mathbf{E F}$} \\
\hline MSE & $\begin{array}{l}0- \\
5,8\end{array}$ & $\begin{array}{l}5,9- \\
11,6\end{array}$ & $11,7-17,5$ & \\
\hline $\begin{array}{l}\text { PENILAIAN } \\
\text { EF }\end{array}$ & 0,75 & 1,25 & 1,5 & \\
\hline
\end{tabular}

6. Penilaian Faktor Pelatihan (Training Factor/TF)

Kondisi terbaik yang ditetapkan pada indikator ini adalah perlu diadakannya pelatihan (minimal 2 tahun sekali).

Tabel 18. Penilaian Faktor Pelatihan (Training Factor/TF) Ruang Cenderawasih (Kondisi Terbaik)

\begin{tabular}{|l|c|c|c|}
\hline \multicolumn{2}{|c|}{ FAKTOR PELATIHAN (TF) } & $\begin{array}{c}\text { PENILAIAN } \\
\text { TF }\end{array}$ & \multirow{2}{*}{$|0,75|$ TF } \\
\hline Pelatihan Diadakan & $\sqrt{ }$ & $\mathbf{0 , 7 5}$ & \\
\hline Hanya Berupa Informasi & & $\mathbf{1}$ & \\
\hline Tidak Ada Pelatihan & & $\mathbf{2}$ & \\
\hline
\end{tabular}

7. Perhitungan Nilai dan Pengklasifikasian Tingkat Paparan MAPO Index

$$
\begin{aligned}
\text { MAPO } & =(0,17 \times 0,5+1,61 \times 0,5) \times 0,75 \times 0,75 \times 0,75 \\
& =(0,084+0,806) \times 0,422 \\
& =0,89 \times 0,422 \\
& =0,375 \approx \text { Dapat Diabaikan (Kode Hijau) }
\end{aligned}
$$

\section{Evaluasi Kondisi Terbaik Ruang Dahlia}

1. Perhitungan Nilai Perbandingan NC/Op \& $\mathrm{PC} / \mathrm{Op}$

Kondisi terbaik yang ditetapkan adalah melakukan penambahan jumlah perawat yang optimal. Berdasarkan metode Douglas, diketahui jumlah perawat optimal pada ruang Dahlia adalah 31 orang,

\begin{tabular}{|c|c|c|}
\hline \multicolumn{3}{|c|}{$\begin{array}{l}\text { JUMLAH PASIEN LUMPUH (BUTUH BANTUAN)/BANYAKNYA } \\
\text { OPERATOR }\end{array}$} \\
\hline $\begin{array}{l}\text { Pasien } \text { Non-Cooperative (NC) _ } 3 \text { _ orang } \\
31=\end{array}$ & Operator & $0,10 \quad \mathbf{N C} / \mathbf{O p}$ \\
\hline $\begin{array}{l}\text { Pasien Partially-Cooperative (PC) _ } 54 \text { _or } \\
31=\end{array}$ & Operator & 1,74 PC/Op \\
\hline
\end{tabular}
dengan jumlah perawat keseluruhan 41 orang.

Tabel 19. Perhitungan Nilai Perbandingan NC/Op \& PC/Op Ruang Dahlia (Kondisi Terbaik)

2. Penilaian Faktor Alat Angkut (Lifting Factor/LF)

Penetapan kondisi terbaik tidak dilakukan mengingat kondisi yang ada sekarang sudah cukup baik bagi ruang rawat.

3. Penilaian Faktor Bantuan Ringan (Minor Aid Factor/AF)

Kondisi terbaik yang ditetapkan pada indikator ini adalah dilengkapinya alat bantu (2 buah Sliding Sheet).

Tabel 20. Penilaian Faktor Bantuan Ringan (Minor Aid Factor/AF) Ruang Dahlia (Kondisi Terbaik)

\begin{tabular}{|l|c|c|c|}
\hline \multicolumn{2}{|c|}{ FAKTOR BANTUAN RINGAN (AF) } & $\begin{array}{c}\text { PENILAIAN } \\
\text { AF }\end{array}$ \\
\cline { 1 - 3 } $\begin{array}{l}\text { Bantuan Ringan TIDAK ADA atau TIDAK } \\
\text { TERSEDIA }\end{array}$ & & $\mathbf{1}$ & $\begin{array}{c}\left\lfloor 0,5 \_\right. \\
\mathbf{A F}\end{array}$ \\
\hline Bantuan Ringan MEMADAI dan TERSEDIA & $\sqrt{ }$ & $\mathbf{0 , 5}$ & \\
\hline
\end{tabular}

4. Penilaian Faktor Kursi Roda (Wheelchair Factor/WF)

Kondisi terbaik yang ditetapkan pada indikator ini adalah dilakukan penambahan kursi roda pada ruang tersebut hingga total kursi roda

\begin{tabular}{|c|c|c|c|c|c|c|c|}
\hline \multicolumn{7}{|c|}{ FAKTOR KURSI RODA (WF) } & \multirow{4}{*}{$\left|-\frac{0,75}{\mathbf{W F}}\right|$} \\
\hline $\begin{array}{l}\text { Nilai Rata-rata Kursi } \\
\text { Roda (MSWh) }\end{array}$ & \multicolumn{2}{|c|}{$0,5-1,33$} & \multicolumn{2}{|c|}{$1,34-2,66$} & \multicolumn{2}{|c|}{$2,67-4$} & \\
\hline $\begin{array}{l}\text { Jumlah Kursi Roda } \\
\text { Memadai }\end{array}$ & YES & NO & YES & NO & YES & NO & \\
\hline PENILAIAN WF & $\mathbf{0 , 7 5}$ & 1 & 1,12 & 1,5 & 1,5 & 2 & \\
\hline
\end{tabular}
berjumlah 29 buah.

Tabel 21. Penilaian Faktor Kursi Roda (Wheelchair Factor/WF) Ruang Dahlia (Kondisi Terbaik)

5. Penilaian Faktor Lingkungan (Environment Factor/EF)

Kondisi terbaik yang ditetapkan pada indikator ini adalah dilakukan perancangan ulang serta melengkapi ataupun mengganti fitur-fitur yang bermasalah terhadap aspek-aspek terkait. Dengan demikian, maka diketahui:

a. Penilaian Kondisi Kamar Rawat Nilai Rata-rata Ruang Rawat (MSW) $=0$

b. Penilaian Kondisi Kamar Mandi Nilai Rata-rata Kamar Mandi $(\mathbf{M S B})=0$

c. Penilaian Kondisi WC/Toilet Nilai Rata-rata WC/Toilet $(\mathbf{M S W C})=0$ 
d. Nilai Rata-rata Lingkungan

Nilai Rata-rata Lingkungan (MSE) $=0$

Tabel 22. Penilaian Faktor Lingkungan (Environment Factor/EF) Ruang Dahlia (Kondisi Terbaik)

\begin{tabular}{|c|c|c|c|c|}
\hline \multicolumn{4}{|c|}{ FAKTOR LINGKUNGAN (EF) } & \multirow{3}{*}{$|0,75| \mathbf{E F}$} \\
\hline MSE & $\begin{array}{l}0- \\
5.8\end{array}$ & $\begin{array}{l}5,9- \\
11,6\end{array}$ & $11,7-17,5$ & \\
\hline $\begin{array}{l}\text { PENILAIAN } \\
\text { EF }\end{array}$ & 0,75 & 1,25 & 1,5 & \\
\hline
\end{tabular}

6. Penilaian Faktor Pelatihan (Training Factor/TF)

Kondisi terbaik yang ditetapkan pada indikator ini adalah perlu diadakannya pelatihan (minimal 2 tahun sekali).

Tabel 23. Penilaian Faktor Pelatihan (Training Factor/TF) Ruang Dahlia (Kondisi Terbaik)

\begin{tabular}{|l|c|c|c|}
\hline \multicolumn{2}{|c|}{ FAKTOR PELATIHAN (TF) } & $\begin{array}{c}\text { PENILAIAN } \\
\text { TF }\end{array}$ \\
\cline { 1 - 2 } \multirow{2}{*}{$\mid \begin{array}{l}\mid 0,75 \\
\text { Pelatihan Diadakan }\end{array}$} & $\mathbf{V}$ & $\mathbf{0 , 7 5}$ \\
\hline Hanya Berupa Informasi & & $\mathbf{1}$ \\
\hline Tidak Ada Pelatihan & & $\mathbf{2}$ & \\
\hline
\end{tabular}

7. Perhitungan Nilai dan Pengklasifikasian Tingkat Paparan MAPO Index

$$
\begin{aligned}
\text { MAPO } & =(0,10 \times 0,5+1,74 \times 0,5) \times 0,75 \times 0,75 \times \\
& =(0,048+0,871) \times 0,422 \\
& =0,92 \times 0,422 \\
& =0,388 \approx \text { Dapat Diabaikan (Kode Hijau) }
\end{aligned}
$$

\section{Perhitungan Kondisi Optimal Ruang Cenderawasih}

Kondisi terbaik ditetapkan pada salah satu indikator, sedangkan indikator lainnya tetap pada kondisi saat ini.

Tabel 24. Rekapitulasi Hasil Perhitungan Kondisi Optimal Ruang Cenderawasih

\begin{tabular}{|l|c|c|}
\hline \multicolumn{1}{|c|}{$\begin{array}{c}\text { Penetapan Kondisi } \\
\text { Terbaik pada Indikator }\end{array}$} & $\begin{array}{c}\text { Nilai } \\
\text { MAPO } \\
\text { Index }\end{array}$ & Tingkat Paparan \\
\hline Nilai Perbandingan NC/Op \& PC/Op & 4,238 & $\begin{array}{c}\text { Menengah } \\
\text { (Sedang) }\end{array}$ \\
\hline $\begin{array}{l}\text { Faktor Bantuan Ringan (Minor Aid } \\
\text { Factor/AF) }\end{array}$ & 2,85 & $\begin{array}{c}\text { Menengah } \\
\text { (Sedang) }\end{array}$ \\
\hline $\begin{array}{l}\text { Faktor Kursi Roda (Wheelchair } \\
\text { Factor/WF) }\end{array}$ & 4,08 & $\begin{array}{c}\text { Menengah } \\
\text { (Sedang) }\end{array}$ \\
\hline
\end{tabular}

Tabel 24. Rekapitulasi Hasil Perhitungan Kondisi Ruang Cenderawasih (Lanjutan)

\begin{tabular}{|l|c|c|}
\hline \multicolumn{1}{|c|}{$\begin{array}{c}\text { Penetapan Kondisi } \\
\text { Terbaik pada Indikator }\end{array}$} & $\begin{array}{c}\text { Nilai } \\
\text { MAPO } \\
\text { Index }\end{array}$ & Tingkat Paparan \\
\hline $\begin{array}{l}\text { Faktor Lingkungan (Environment } \\
\text { Factor/EF) }\end{array}$ & 3,26 & $\begin{array}{c}\text { Menengah } \\
\text { (Sedang) }\end{array}$ \\
\hline Faktor Pelatihan (Training Factor/TF) & 2,04 & $\begin{array}{c}\text { Menengah } \\
\text { (Sedang) }\end{array}$ \\
\hline
\end{tabular}

Nilai MAPO Index paling rendah diperoleh pada penetapan kondisi terbaik untuk Faktor Pelatihan (Training Factor/TF), oleh sebab itu, perlu dilakukan kembali perhitungan kondisi optimalnya dengan menetapkan kondisi terbaik pada nilai TF untuk semua perhitungan:

\begin{tabular}{|c|c|c|}
\hline $\begin{array}{c}\text { Penetapan Kondisi } \\
\text { Terbaik pada Indikator }\end{array}$ & $\begin{array}{c}\text { Nilai } \\
\text { MAPO } \\
\text { Index }\end{array}$ & Tingkat Paparan \\
\hline Nilai Perbandingan NC/Op \& PC/Op + TF & 1,59 & $\begin{array}{c}\text { Menengah } \\
\text { (Sedang) }\end{array}$ \\
\hline $\begin{array}{l}\text { Faktor Bantuan Ringan (Minor Aid Factor/AF) } \\
+\mathrm{TF}\end{array}$ & 1,07 & Dapat Diabaikan \\
\hline $\begin{array}{l}\text { Faktor Kursi Roda (Wheelchair Factor/WF) + } \\
\text { TF }\end{array}$ & 1,53 & $\begin{array}{c}\text { Menengah } \\
\text { (Sedang) }\end{array}$ \\
\hline $\begin{array}{l}\text { Faktor Lingkungan (Environment Factor/EF) + } \\
\text { TF }\end{array}$ & 1,22 & Dapat Diabaikan \\
\hline
\end{tabular}

Tabel 25. Rekapitulasi Hasil Perhitungan Kondisi Optimal Ruang Cenderawasih (dengan Penetapan Kondisi Terbaik pada Training Factor)

\section{Perhitungan Kondisi Optimal Ruang Dahlia}

Kondisi terbaik ditetapkan pada salah satu indikator, sedangkan indikator lainnya tetap pada kondisi saat ini.

Tabel 26. Rekapitulasi Hasil Perhitungan Kondisi Optimal Ruang Dahlia

\begin{tabular}{|l|c|c|}
\hline \multicolumn{1}{|c|}{$\begin{array}{c}\text { Penetapan Kondisi } \\
\text { Terbaik pada Indikator }\end{array}$} & $\begin{array}{c}\text { Nilai } \\
\text { MAPO } \\
\text { Index }\end{array}$ & Tingkat Paparan \\
\hline Nilai Perbandingan NC/Op \& PC/Op & 4,475 & $\begin{array}{c}\text { Menengah } \\
\text { (Sedang) }\end{array}$ \\
\hline $\begin{array}{l}\text { Faktor Bantuan Ringan (Minor Aid } \\
\text { Factor/AF) }\end{array}$ & 2,97 & $\begin{array}{c}\text { Menengah } \\
\text { (Sedang) }\end{array}$ \\
\hline Faktor Kursi Roda (Wheelchair & 4,34 & $\begin{array}{c}\text { Menengah } \\
\text { (Sedang) }\end{array}$ \\
\hline $\begin{array}{l}\text { Factor/WF) } \\
\text { Factor/EF) }\end{array}$ & 3,47 & $\begin{array}{c}\text { Menengah } \\
\text { (Sedang) }\end{array}$ \\
\hline Faktor Pelatihan (Training Factor/TF) & 2,17 & $\begin{array}{c}\text { Menengah } \\
\text { (Sedang) }\end{array}$ \\
\hline
\end{tabular}

Nilai MAPO Index paling rendah diperoleh pada penetapan kondisi terbaik untuk Faktor Pelatihan (Training Factor/TF), oleh sebab itu, perlu dilakukan kembali perhitungan kondisi optimalnya dengan menetapkan kondisi terbaik pada nilai TF untuk semua perhitungan:

Tabel 27. Rekapitulasi Hasil Perhitungan Kondisi Optimal Ruang Dahlia (dengan Penetapan Kondisi Terbaik pada Training Factor)

\begin{tabular}{|l|c|c|}
\hline \multicolumn{1}{|c|}{$\begin{array}{c}\text { Penetapan Kondisi } \\
\text { Terbaik pada Indikator }\end{array}$} & $\begin{array}{c}\text { Nilai } \\
\text { MAPO } \\
\text { Index }\end{array}$ & Tingkat Paparan \\
\hline Nilai Perbandingan NC/Op \& PC/Op + TF & 1,68 & $\begin{array}{c}\text { Menengah } \\
\text { (Sedang) }\end{array}$ \\
\hline $\begin{array}{l}\text { Paktiofrhat } \\
+ \text { TF }\end{array}$ & 1,11 & Dapat Diabaikan Ringan (Minor Aid Factor/AF) \\
\hline $\begin{array}{l}\text { Faktor Kursi Roda (Wheelchair Factor/WF) + } \\
\text { TF }\end{array}$ & 1,63 & $\begin{array}{c}\text { Menengah } \\
\text { (Sedang) }\end{array}$ \\
\hline $\begin{array}{l}\text { Faktor Lingkungan (Environment Factor/EF) + } \\
\text { TF }\end{array}$ & 1,3 & Dapat Diabaikan \\
\hline
\end{tabular}

\section{Kesimpulan}

Tingkat paparan gangguan muskuloskeletal yang terjadi pada perawat berada pada kategori Tinggi (Kode Merah), dengan hasil penilaian MAPO Index yaitu pada ruang Cenderawasih diperoleh nilai sebesar 5,44 dan pada ruang Dahlia diperoleh nilai sebesar 5,78. Hal ini disebabkan oleh permasalahan yang terdapat pada hampir seluruh indikator penilaian MAPO Index (kecuali Faktor Alat Angkut (Lifting Factor/LF), antara lain 
perbandingan jumlah perawat yang belum terlalu optimal dibanding dengan jumlah pasien, alat bantu yang tidak tersedia di kedua ruang rawat, jumlah kursi roda yang tidak memadai, kondisi ruang rawat maupun kamar mandi termasuk WC/Toilet yang kurang ergonomis, serta fitur-fitur terkait yang kurang memadai, dan tidak adanya pelatihan yang dilakukan.

Adapun usulan untuk masing-masing ruang rawat yaitu, pada ruang Cenderawasih perlu dilakukan penambahan perawat sebanyak 6 orang, melengkapi alat bantu untuk memindahkan pasien, melakukan penambahan unit kursi roda sebanyak 14 buah, melakukan evaluasi ulang serta melengkapi ataupun mengganti fitur-fitur yang bermasalah terhadap aspek-aspek terkait, dan mengadakan pelatihan bagi perawat. Untuk ruang Dahlia perlu dilakukan penambahan perawat sebanyak 6 orang, melengkapi alat bantu untuk memindahkan pasien, melakukan penambahan unit kursi roda sebanyak 25 buah, melakukan evaluasi ulang serta melengkapi ataupun mengganti fitur-fitur yang bermasalah terhadap aspek-aspek terkait, dan mengadakan pelatihan bagi perawat.

Berdasarkan perhitungan kondisi optimal di kedua ruang rawat diketahui bahwa penetapan kondisi terbaik yang dilakukan pada Faktor Pelatihan (Training Factor/TF) dan Faktor Bantuan Ringan (Minor Aid Factor/AF) sudah cukup untuk memperoleh nilai MAPO index yang berada pada kategori tingkat paparan 'Dapat Diabaikan', sehingga usulan perbaikan optimalnya yaitu perlu diadakan pelatihan bagi perawat serta dilengkapinya alat bantu untuk memindahkan pasien.

\section{Daftar Pustaka}

Battevi, N., Menoni, O., Ricci, M.G. \& Cairoli, S. "MAPO Index for Risk Assessment of Patient Manual Handling in Hospital Wards: a Validation Study", Taylor \& Francis Group. Ergonomics Vol. 49, No. 7, hal. 671-687, 10 Juni 2006.

Bukhori, E. "Hubungan Faktor Risiko Pekerjaan dengan Terjadinya Keluhan Musculoskeletal Disorders (MSDs) pada Tukang Angkut Beban Penambang Emas di Kecamatan Cilograng Kabupaten Lebak Tahun 2010", Skripsi Program Studi Kesehatan Masyarakat, Fakultas Kedokteran dan Ilmu Kesehatan, Universitas Islam Negeri Syarif Hidayatullah, Jakarta. 2010.

Elyas, Y. "Gambaran Tingkat Risiko Musculoskeletal Disorders (MSDs) pada Perawat Saat Melakukan Aktivitas Kerja di Ruang ICU PJT RSCM Berdasarkan Metode Rapid Entire Body Assesment
(REBA)", Skripsi Program Studi Keperawatan, Fakultas Ilmu Keperawatan, Universitas Indonesia, Depok. 2012.

Kurniawidjaja, L.M., Purnomo, E., Maretti, N. \& Pujiriani, I. "Pengendalian Risiko Ergonomi Kasus Low Back Pain pada Perawat di Rumah Sakit", $M K B$. Volume 46, No. 4, Desember 2014.

Mas'idah, E., Fatmawati, W. \& Ajibta, L. “Analisa Manual Material Handling (MMH) dengan Menggunakan Metode Biomekanika untuk Mengidentifikasi Resiko Cidera Tulang Belakang (Musculoskeletal Disorder) (Studi Kasus pada Buruh Pengangkat Beras di Pasar Jebor Demak)", Sultan Agung. Vol XLV, No. 119, September - Nopember 2009.

Pangaribuan, D.M. “Analisa Postur Kerja dengan Metode RULA pada Pegawai Bagian Pelayanan Perpustakaan USU Medan", Skripsi Program Pendidikan Sarjana Ekstensi, Departemen Teknik Industri, Fakultas Teknik, Universitas Sumatera Utara, Medan. 2009.

Stanton, N., Hedge, A., Brookhuis, K., Salas, E. \& Hendrick, H. "Handbook of Human Factor and Ergonomics Methods". Boca Raton, Florida: CRC Press LLC, 2005.

Sukania, I.W., Widodo, L. \& Natalia, D. "Identifikasi Keluhan Biomekanik dan Kebutuhan Operator Proses Packing di PT X”. Jurnal Energi dan Manufaktur. Vol. 6, No.1, April 2013.

Sukardi, H. "Analisis Kebutuhan Tenaga Perawat Berdasarkan Kategori Pasien di Irna Penyakit Dalam RSU Tugurejo Semarang”, Tesis Program Studi Magister Ilmu Kesehatan Masyarakat, Konsentrasi Administrasi Rumah Sakit, Universitas Diponegoro Semarang, Semarang. 2005.

Wikipedia."HumanMusculoskeletalSystem "[Onlin e]Availablehttps://en.wikipedia.org/wiki/Hu man_musculoskeletal_system,diakses6Nop ember 2015. 